\title{
NOTARIS DALAM SENGKETA PERBANKAN SYARIAH ${ }^{1}$
}

\author{
Ro'fah Setyowati \\ Fakultas Hukum Universitas Diponegoro \\ Jl. Prof. Sudarto, Tembalang Semarang \\ Email: rofahundip@gmail.com
}

\begin{abstract}
Notary responsible for any agreement made. Shariah contract has a special character. Considering one of the factors that influence the dispute is the issue of the contract, this research aims to explore about the responsibility of the Notary of the contract in the context of Islamic banking disputes. This type of research is a normative juridical with qualitative analysis. The result, in some dispute, indicated that not the Notary yet understand enough abaut the contract sharia. While, for this purpose, there should be standardization of competence. Accordingly, necessary related materials, in the MKn curriculum.
\end{abstract}

Keywords: Notary; Dispute; Islamic Banking.

\begin{abstract}
Abstrak
Notaris bertanggungjawab terhadap setiap akad yang dibuat. Akad syariah mempunyai karakter khusus. Mengingat salah satu faktor yang mempengaruhi sengketa ialah persoalan akad, maka penelitian ini bertujuan menggali tentang tanggungjawab Notaris terhadap akad dalam konteks sengketa perbankan syariah. Jenis penelitian ini ialah yuridis normatif dengan analisis kualitatif. Hasilnya, pada sebagian sengketa, terindikasi bahwa belum banyak Notaris yang paham akad syariah. Sementara, untuk keperluan ini, semestinya ada standarisasi kompetensi. Berdasarkan hal tersebut, perlu materi terkait, dalam kurikulum MKn.
\end{abstract}

Kata Kunci: Notaris; Sengketa; Perbankan Syariah.

\section{A. Pendahuluan}

\section{Latar Belakang Permasalahan}

Notaris merupakan pejabat umum yang mempunyai tugas dan kewajiban untuk memberikan pelayanan dan konsultasi hukum kepada masyarakat yang membutuhkan. Jika dikaitkan dengan pesatnya perkembangan perbankan syariah di Indonesia dan berbagai belahan dunia, maka kedudukan Notaris mempunyai posisi strategis, khususnya dalam pembuatan akta atau dalam literatur perbankan syariah, lebih lazim disebut dengan akad. ${ }^{2}$

Terhadap akad yang dibuat, Notaris mempunyai tanggungjawab penuh, tentang kebenaran konstruksi akad, agar terpenuhinya syarat-syarat perjanjian. Tanggung jawab dimaksud terhitung sejak suatu akad dibuat, hingga masa daluwarsa sebagaimana ditetapkan oleh Undang-undang. Dengan demikian, manakala terjadi sengketa perbankan syariah yang ditimbulkan oleh akad, terlebih pada akad yang dinyatakan tidak sah dan atau batal demi hukum, maka Notaris tidak dapat lepas dari tanggungjawab terhadap peristiwa tersebut. Hal demikian mengingat kedudukan akta notariil sangat penting sebagai alat bukti dalam penyelesaian

1. Artikel ini merupakan pengembangan dari sebagian dari hasil penelitian tentang "Penataan Sistem Hukum Perbankan Syariah Melalui Harmonisasi Hukum Penyelesaian Sengketa Dengan Pendekatan Hukum Progresif" yang didanai oleh Departemen Perbankan Syariah OJK, dalam Program iB FELLOSHIP PROGRAM, 2015. Dipresentasikan dalam Diskusi Publik "Notaris dan Perbankan Syariah", Ikatan Mahasiswa Magister Kenotariatan (IMMKn), FH UNDIP, 19 September 2015.

2. Deni K. Yusup, "Peran Notaris Dalam Praktek Perjanjian Bisnis Di Perbankan Syariah (Tinjauan Dari Perspektif Hukum Ekonomi Syariah)”, Jurnal Al 'Adalah, Vol. XXI, No. 4, Desember 2015, hlm. 701. 
sengketa. ${ }^{3}$ Salah satu contoh terkait dengan keterlibatan Notaris dengan sengketa perbankan syariah ialah pada Keputusan No. 01/P/Basy.PJT/VII/2010 antara Haji Mochamad Logika melawan PT. Bank Syariah Mega Indonesia, Cabang Semarang, menyatakan bahwa Akta No. 14 Tentang Perjanjian Pembiayaan Rekening Koran Musyarakah dari PT. Bank Syariah Mega Indonesia, dinyatakan tidak sah dan batal demi hukum. Hal mana, terkait dengan akad tersebut, hingga kini sengketa yang terjadi antara nasabah dengan perbankan syariah. Penelitian ini dimaksudkan untuk menemukan solusi bagi permasalahan hokum terkait dengan tanggungjawab Notaris dalam sengketa perbankan syariah. Secara rinci, permasalahan hukum yang perlu dibahas terkait dengan topik penelitian ini ialah : 1) Perbankan syariah dan konsekwensi filosofis yuridis; 2) Tanggung Jawab Notaris Terhadap Akad Perbankan Syariah Yang dinyatakan Tidak Sah.

\section{Metode Penelitian}

Penelitian yang terkait dengan topik ini menekankan penelitian doktrinal. Pendekatan yang digunakan antara lain : historis; pendekatan filosofis; serta pendekatan analitis dan kritis. Penggunaan metode tersebut didasarkan pada tujuan penelitian untuk melihat lebih jauh tentang tanggungjawab notaris pada bank syariah dalam hal terjadinya sengketa. Metode pengumpulan data menggunakan penelusuran kepustakaan, dengan mengkaji berbagai hasil putusan lembaga penyelesai sengketa; perundang-undangan dan kebijakan terkait dengan notaris, perbankan syariah dan sengketa. Adapun analisis penelitian ini dilakukan secara kualitatif. ${ }^{4}$

\section{Kerangka Teori}

Dalam kerangka teori ini, penting untuk diulas beberapa teoro tentang hokum, fungsi hokum dan hubungan antara hokum dengan masyarakat dalam konteks fungsi notaris.

\section{a. Pengertian Tentang Hukum}

Dalam teori kedaulatan Negara (sovereignity law theory) yang dicetuskan oleh Krabbe, sebagaimana dikutip oleh Salim, ${ }^{5}$ dinyatakan bahwa yang memiliki kekuasaan tertinggi dalam suatu Negara itu adalah hukum itu sendiri. Berdasar teori tersebut, maka baik raja, penguasa maupun rakyat atau warga negara, bahkan negara itu sendiri, semuanya tunduk pada hukum.

Terkait dengan pengertian hokum, J.C.T Simorangkir dan Woerjono Sastropranoto sebagaimana kutipan Kansil, ${ }^{6}$ memberi definisi hukum yaitu: "Hukum ialah peraturan-peraturan yang bersifat memaksa, yang menentukan tingkah laku manusia dalam lingkungan masyarakat yang dibuat oleh badanbadan resmi yang berwajib, pelanggaran mana terhadap peraturan-peraturan berakibatkan diambilnya tindakan, yaitu dengan hukuman tertentu”. Secara lebih luas, Joseph T. Bockrath ${ }^{7}$ juga memberikan pengertian hokum, antara lain:1) Hukum, berarti aturan perilaku sipil; yaitu perintah apa yang benar dan melarang apa yang salah. 2) Hukum merupakan aturan dimana individu dan masyarakat beradab hidup dan mempertahankan hubungan mereka satu sama lain. Hal ini mencakup semua pengundangan legislative.

Masih berkait dengan hukum bagi sesebuah masyarakat, Kamenka mempunyai pandangan bahwa hukum mempunyai peranan atau berfungsi dengan tiga tanggungjawab yang berbeda tetapi berkaitan dengan masyarakat. Pertama ialah hukum

\footnotetext{
3. Yulies Tiena Masriani, “The Position of Notariial Deed in the Syaria Economic Dispute”, Mimbar Hukum, Vol. 28, No. 1, Februari 2016, hlm. 162-173.

4. Amirudin dan Zainal Asikin, 2013, Pengantar Metode Penelitian Hukum, Jakarta, Raja Grafindo Perkasa, hlm. 168171.

5. Salim H.S, 2012, Perkembangan Teori dalam Ilmu Hukum, Cetakan Kedua, Jakarta, PT Rajagrafindo Persada,

6. hlm.135.

7. Joseph T. Bockrath, 2000, Contracts and The Legal Environment for Engineers and Architects, United States of America, The McGraw-Hill Companies, Inc, hlm 5.

8. E. Kamenka \& Alice Erh-Soon Toy, 1979, Justice, London, Edward Arnold, hlm 4-5.
} 
berfungsi menjalankan asas peraturan kehidupan bersama. Hal ini dapat dicapai dengan menghubungkannya dengan nilai-nilai kehidupan dan hukum yang baik. Tanggungjawab kedua, hukum mengadakan prinsip dan prosedur untuk menyelesaikan setiap konflik dan sengketa dalam masyarakat, dan masyarakat harus memahami bahwa mereka perlu akur dan patuh terhadap hukum yang diadakan. Tanggungjawab ketiga, hukum menjamin dan memberikan keamanan terhadap hubungan yang terdapat dalam masyarakat dengan menekankan kepentingan prinsip dan kebijakan.

Lebih jauh dalam tataran praktis, khususnya dalam konteks penegakan hukum, me nurut Sudikno Mertokusumo, terdapat tiga unsur yang harus diperhatikan, yaitu : kepastian hukum (rechtssicherheit), kemanfaatan (zweckmassigkeit), dan keadilan (gerechtigkeit). Ketiga unsur tersebut oleh Gustav Radbruch sebagaimana dikutip Satjipto Rahardjo ${ }^{10}$ disebut sebagai penopang cita hukum (idee des Rechts). Cita hukum dimaksud merupakan suatu arah yang akan membimbing manusia pada kehidupannya, khususnya dalam berhukum. Sejalan dengan pandangan tersebut, Hans Kelsen juga menyatakan bahwa, A legal norm empowers certain individuals to create legal norms or to apply legal norms ${ }^{11}$ (Norma hukum memberdayakan individu-individu tertentu untuk membuat norma-norma hukum atau menerapkan norma-norma hukum).

Dari uarian singkat tentang eksistensi, pengertian dan peranan hukum dalam masyarakat dapat dipahami bahwa hukum dibuat untuk mengatur kehidupan masyarakat, sebagai makhluk sosial untuk memenuhi berbagai kebutuhan yang berkembang dari masa ke masa, seiring dengan dinamika perkembangan masyarakatnya. Kehidupan masyarakat yang bersifat dinamis memerlukan kepastian, ketertiban dan perlindungan hokum, tidak terkecuali dalam sektor jasa layanan publik. Dalam konteks kajian ini, peranan hukum dijalankan oleh Notaris, sebagai profesi yang bergerak dalam bidang layanan publik.

\section{b. Dasar Hukum Notaris}

Berdasarkan Undang-Undang Nomor 2 Tahun 2014 tentang Perubahan atas Undang-Undang Nomor 30 Tahun 2004 tentang Jabatan Notaris, dapat dikenali bahwa peran Notaris dalam sektor pelayanan jasa adalah sebagai pejabat yang diberi sebagian kewenangan oleh Negara untuk melayani masyarakat dalam bidang perdata khususnya pembuatan akta otentik. Hal tersebut mengingat bahwa lembaga ini timbul dari kebutuhan dalam pergaulan sesama manusia yang menghendaki adanya suatu alat bukti mengenai hubungan hukum keperdataan yang ada dan atau terjadi diantara mereka". ${ }^{12}$ Dengan demikian, Notaris merupakan seorang pejabat tempat seseorang dapat memperoleh nasihat yang dapat diandalkan. Segala sesuatu yang ditulis serta ditetapkannya (konstatir) adalah benar ia adalah pembuat dokumen yang kuat dalam suatu proses hukum. ${ }^{13}$

\section{c. Pengertian Perbankan Syariah}

Perbankan syariah telah diakui dan dimuat secara legal formal di Indonesia, sebagaimana dituangkannya istilah 'prinsip syariah' dalam Undang-undang Nomor 21 Tahun 2008 tentang Perbankan Syariah (UUPS). Perbankan syariah dapat dipahami pengertiannya melalui beberapa pasal yang secara khusus menyebut eksistensi 'prinsip

9. Sudikno Mertokusumo, Mr. A. Pitlo, 1993, Bab-bab Tentang Penemuan Hukum, Bandung, PT. Citra Aditya Bakti, hlm. 3 .

10. Satjipto Rahardjo, 2006, Hukum Dalam Jagat Ketertiban, Cetakan I, Jakarta, UKI Press, hlm. 135.

11. Hans Kelsen, 1991, General Theory of Norms, terjemahan Michael Hartney, New York, Oxford University Press, hlm.102.

2. G.H.S Lumban Tobing, 1999, Peraturan Jabatan Notaris, Jakarta, Erlangga, hlm.2.

13. Tan Thong Kie, 2011, Studi Notariat dan Serba -Serbi Praktek Notaris, Cetakan Kedua, Jakarta, PT. Ichtiar Baru van Hoeve, hlm 444. 
syariah' sebagaimana dalam Tabel 1.

Tabel 1. Prinsip Syariah dalam Undang-Undang Perbankan Syariah

\begin{tabular}{|l|l|}
\hline \multicolumn{1}{|c|}{ Pasal } & \multicolumn{1}{|c|}{ Muatan } \\
\hline Pasal 1 ayat 7 & $\begin{array}{l}\text { Bank Syariah adalah bank yang menjalankan kegiatan usahanya } \\
\text { berdasarkan Prinsip Syariah. Menurut jenisnya terdiri atas Bank } \\
\text { Umum Syariah (BUS) dan Bank Pembiayaan Rakyat Syariah } \\
\text { (BPRS). }\end{array}$ \\
\hline Pasal 1 ayat 12 & $\begin{array}{l}\text { Prinsip syariah adalah prinsip hukum Islam dalam kegiatan } \\
\text { perbankan berdasarkan fatwa yang dikeluarkan oleh institusi yang } \\
\text { memiliki kewenangan dalam penetapan fatwa di bidang syariah. }\end{array}$ \\
\hline Pasal 1 ayat 13 & $\begin{array}{l}\text { Akad adalah kesepakatan tertulis antara Bank Syariah atau UUS dan } \\
\text { pihak lain yang memberikan pengaturan adanya hak dan kewajiban } \\
\text { bagi masing-masing pihak sesuai dengan Prinsip Syariah. }\end{array}$ \\
\hline Pasal 1 ayat 19 & $\begin{array}{l}\text { Nasabah penerima fasilitas adalah nasabah yang memperoleh } \\
\text { fasilitas dana atau yang dipersamakan dengan itu, berdasarkan } \\
\text { prinsip syariah. }\end{array}$ \\
\hline Pasal 2 & $\begin{array}{l}\text { Perbankan Syariah dalam melakukan kegiatan usahanya } \\
\text { berasaskan prinsip syariah, demokrasi ekonomi, dan prinsip kehati- } \\
\text { hatian. }\end{array}$ \\
\hline
\end{tabular}

B. Hasil dan Pembahasan

1. Perbankan syariah Dan Konsekwensi Filosofis Yuridis

Uraian tentang perbankan syariah dan konsekwensi filosofis yuridis penting dilakukan, mengingat pemahaman filosofis tentang perbankan syariah ini akan mendasari dan menjadi pedoman berbagai kajian yang dikembangkan. Sebagai pedoman dalam hal ini dimaksudkan untuk memberikan arah pemahaman yang benar tentang perbankan syariah, sebagaimana asal muasal konsep bank syariah tersebut dibangun dan kemudian dioperasionalkan. Lebih jauh, pandangan filosofis ini juga menyentuh pada motivasi yang menggerakkan kehadiran lembaga perbankan syariah, berupa kesadaran terhadap pengamalan hukum Islam, terkait dengan aspek ekonomi, khususnya pada transaski perbankan. Oleh karenanya, pembahasan dari perspektif filosofis ini, mengangkat tentang hubungan antara aktifitas perbankan dengan hukum Islam.
Dengan demikian, hubungan antara perbankan syariah dengan prinsip-prinsip syariah merupakan hubungan filosofis dalam konteks untuk mengamalkan hukum Islam secara kaffaah (menyeluruh). Sedangkan dari tabel 1 di atas, muatan beberapa pasal UUPS, menunjukkan kuatnya komitmen terhadap prinsip-prinsip syariah. Komitmen demikian menunjukkan adanya hubungan filosofis yuridis antara perbankan syariah dengan hukum Islamdi Indonesia.

Dalam hal ini, jika hubungan antara bank syariah dengan hukum Islam dilihat dari perspektif kelembagaan bank syariah, maka pernyataan sebuah lembaga keuangan, yang ingin menerapkan syariah dan atau menggunakan label syariah dalam operasional usahanya, maka harus dengan perijinan khusus. Berbagai peraturan perundangan dari level undang-undang hingga peraturan teknis telah memberikan unsur pembeda, meskipun pada sebagian lainnya masih tetap sama. Perbedaan sejak 
dalam perijinan hingga tahap operasional demikian pada dasarnya merupakan wujud dari 'corporate identity' sebuah lembaga usaha. Label syariah yang merupakan pencerminan dari coroporate identity tersebut, dari perspektif hukum mempunyai konsekwensi yuridis tertentu, mengingat label syariah pada dasarnya merupakan bentuk penundukan dari pada sistem hukum Islam dalam lingkup dan konteks yang dimaksud. Pemakaian kata 'syariah' yang menunjuk pada makna 'syariah Islam' sebagai sumber legislasi, tampak secara khusus pada pencantuman "syariah", seperti misalnya 'perbankan syariah', 'asuransi syariah', 'ekonomi syariah' dan lain sebagainya. Prinsip syariah berlandaskan pada nilai-nilai keadilan, kemanfatan, keseimbangan dan keuniversalan (rahmatan lil'alamin). Nilainilai tersebut diterapkan dalam pengaturan perbankan, sehingga disebut Perbankan Syariah. Dengan demikian dapat disimpulkan bahwa jika sebuah bank menyatakan diri sebagai bank syariah, maka terhadap dirinya (bank tersebut), berlaku hukum Islam, selain hukum perbankan pada umumnya.

Hubungan seorang muslim dengan hukum Islam secara jelas dapat ditunjukkan dengan teori kredo. Teori ini menekankan konsekwensi pernyataan kesaksian seseorang atas pengakuan Allah SWT sebagai illah, dan Muhammad SAW sebagai rusulullah. Pernyataan dalam bentuk deklarasi demikian, dikenal dengan istilah 'syahadat'.

Dari persepektif hukum, seorang yang menyatakan diri sebagai muslim, dengan wujud deklarasi syahadat tersebut di atas, maka sejak saat itu, berlakulah baginya sistem hukum Islam, sesuai dengan tahap dan kebutuhan dalam kehidupannya.

Dikaitkan dengan konteks kajian ini, dalam perspektif hukum Islam, setiap transaksi, baik yang dilakukan oleh individu maupun lembaga dalam bidang apapun, termasuk di dalamnya bidang ekonomi, terikat dengan nilai-nilai Islam. Dalam istilah sehari-hari, perbuatan tersebut terikat dengan ketentuan halal-haram. Sementara persoalan halal-haram merupakan salah satu lingkup kajian hukum Islam. Oleh karenanya, maka hal tersebut menunjukkan keterkaitan yang erat antara hukum, ekonomi dan syariah. Bagi seorang muslim, 'spirit' kehidupannya lebih banyak bersumber dari keyakinan agama Islam. Persoalan spiritual sangat penting bagi masyarakat bereligiusitas tinggi, sebagaimana Indonesia.

\section{Tanggung Jawab Notaris Terhadap Akad Yang dinyatakan Batal Demi Hukum Dalam Sengketa Perbankan Syariah \\ Tanggung jawab Notaris terhadap akad} perbankan syariah mempunyai cakupan uraian yang lebih luas dibandingkan dengan bank konvensional, mengingat pada perbankan syariah, terdapat unsur religiusitas dan atau spiritualitas yang melekat. Lekatnya aspek tersebut, sebagaimana dapat dilihat dari Tabel 1. Dengan kata lain, seorang Notaris perbankan syariah, selain dituntut untuk memahami berbagai hukum barat dan nasional yang terkait dengan muatan akad, juga wajib menguasai tentang hukum Islam yang terkait dengan muatan akad yang dibuat.

Berkaitan dengan pernyataan akad batal demi hukum pada putusan tersebut, salah satu pertimbagan hukumyang diambil para arbiter ialah bahwa perjanjian tidak sesuai dengan akad musyarakah, meskipun dilakukan atas persetujuan para pihak, maka dalam hal ini para pihak telah melanggar prinsip syariah, karena ketentuan syariah mengajarkan kejujuran dan iktikad baik, serta kesesuaian antara isi perjanjian dengan pelaksanaannya. Berdasarkan muatan putusan terebut, maka dapat dipahami bahwa Notaris sebagai pembuat akta perjanjian tersebut, belum cukup mempunyai pemahaman tentang karakter perbankan syariah beserta keragaman produk dan skeem akadnya. Ketidakfahaman ini menjadi awal permasalahan, manakala para pihak telah menyerahkan kepercayaan bahwa Notaris ialah orang yang paham dengan bernbagai hal yang dibuat dalam suatu akad, dengan berbagai konsekwensi yuridisnya.

Mengenai definisi dari akta otentik dituangkan dalam Pasal 1868 KUHPerdata yaitu sebagai berikut: "suatu akta otentik ialah suatu akta yang didalam bentuk yang ditentukan oleh undang-undang, dibuat oleh atau dihadapan pegawai-pegawai umum yang berkuasa untuk itu ditempat dimana akta dibuatnya". Lebih jauh menurut Sudikno, 
akta adalah surat yang diberi tanda tangan, yang memuat peristiwa yang menjadi dasar suatu hak atau perikatan, yang dibuat sejak semula dengan sengaja untuk pembuktian. ${ }^{14}$

Senada dengan Sudikno, R. Tresna menyatakan, "pada umumnya akta itu adalah suatu surat yang ditandatangani, memuat keterangan tentang kejadian-kejadian atau hal-hal yang merupakan dasar dari suatu hak atau suatu perjanjian, dapat dikatakan bahwa akta itu ialah suatu tulisan dengan mana dinyatakan sesuatu perbuatan hukum". Melalui akta yang dibuatnya, Notaris harus dapat memberikan kepastian hukum kepada masyarakat pengguna jasa Notaris. ${ }^{16}$ Akta notaris adalah akta otentik yang memiliki kekuatan hukum dengan jaminan kepastian hukum sebagai alat bukti tulisan yang sempurna (volledig bewijs), tidak memerlukan tambahan alat pembuktian lain, dan hakim terikat karenanya. Selain itu, akta otentik merupakan produk Notaris yang sangat dibutuhkan masyarakat demi terciptanya suatu kepastian hukum. Akta otentik sebagai alat bukti yang terkuat dan terpenuh memiliki peranan penting dalam setiap hubungan hukum dalam masyarakat, baik hubungan bisnis/kerjasama, kegiatan dibidang pertanahan, perbankan, kegiatan sosial dan dalam kebutuhan hidup lainnya.

Berdasarkan Pasal 1870 dan 1871 Kitab Undang-Undang Hukum Perdata (selanjutnya disebut KUH Perdata), dinyatakan bahwa, "akta otentik itu adalah alat pembuktian yang sempurna bagi kedua belah pihak dan ahli warisnya serta sekalian orang yang mendapat hak darinya tentang apa yang dimuat dalam akta tersebut". Dengan kata lain, akta otentik merupakan bukti yang lengkap (mengikat). Teguh ${ }^{18}$ menegaskan bahwa hal tersebut bermakna hal -hal yang tertulis dalam akta tersebut dianggap sebagai benar, selama kebenarannya itu tidak ada pihak lain yang dapat membuktikan sebaliknya.

Dalam suatu akta, tertuang perjanjian antara para pihak yang membuatnya. Perjanjian yang sah adalah perjanjian yang memenuhi syarat-syarat yang ditetapkan oleh undang-undang. Perjanjian yang sah diakui dan diberi akibat hukum (legally concluded contract).${ }^{19} \mathrm{Akad}$ (perjanjian) merupakan Undang-Undang bagi mereka yang membuatnya sebagaimana ketentuan Pasal 1338 KUH Perdata, namun suatu akad tidak boleh bertentangan dengan Undang-Undang, terlebih lagi Undang-Undang yang telah menetapkan adanya kekuasaan mutlak bagi suatu badan peradilan yang mengikat para pihak yang melakukan perjanjian. Hal ini yang biasa dikenal dengan asas kebebasan berkontrak dalam perjanjian.

Akad atau perjanjian tersebut merupakan hukum yang mengikat bagi para pihak yang melakukan akad atau perjanjian tersebut (vide Pasal 1338 KUHPerdata). Namun demikian, perjanjian atau akad tersebut harus memenuhi syarat-syarat yang ditentukan oleh Undang-Undang (vide Pasal 1320 KUHPerdata). Dalam Pasal 1320 KUHPerdata tersebut ditentukan bahwa untuk sahnya suatu perjanjian diperlukan empat syarat, yaitu/ 1. Sepakat mereka yang mengikatkan dirinya; 2. Kecakapan untuk membuat suatu perikatan; 3. Suatu hal tertentu; 4. Suatu sebab yang halal. “... suatu sebab yang halal', maka sebab dibuatnya akad atau perjanjian tersebut harus sesuai dengan ketentuan Pasal 1337 KUHPerdata yang menyatakan bahwa "Suatu sebab adalah terlarang, apabila dilarang oleh undangundang, atau apabila berlawanan dengan kesusilaan baik atau ketertiban umum". Perjanjian atau akad yang tidak memenuhi syarat tersebut menjadi batal demi hukum.

Lebih jauh tentang akad yang merupakan suatu perjanjian, dapat dikatakan sah menurut hukum apabila telah terpenuhi syarat-syarat yang tercantum dalam Pasal 1320 KUH Perdata. Menurut Pasal 1320 KUH Perdata, syarat sah perjanjian sebagai berikut: 1) Sepakat mereka yang mengikatkan

14. Sudikno Mertokusumo, 1993, Hukum Acara Perdata Indonesia, Edisi Keempat, Yogyakarta, Liberty, hlm.121.

15. R. Tresna, 1993, Komentar HIR, Jakarta, Pradnya Paramita, hlm.142.

16. H. Salim HS. dan H. Abdullah, 2007, Perancangan Kontrak dan MOU, Jakarta, Sinar Grafika, hlm.101-102.

17. A.A. Andi Prajitno, 2010, Apa dan Siapa Notaris di Indonesia?, Cetakan Pertama, Surabaya, Putra Media Nusantara, hlm. 51 .

18. Teguh Samudera, 2004, Hukum Pembuktian dalam Acara Perdata, Edisi Pertama, Bandung, Alumni, hlm.49.

19. Sudikno Mertokusumo, 1993, Hukum Acara Perdata Indonesia, Edisi Keempat, Yogyakarta, Liberty, hlm.228. 
dirinya; 2 Kecakapan untuk membuat suatu perikatan; 3) Suatu hal tertentu; 4) Suatu sebab yang halal. Sepakat artinya mereka yang mengikatkan dirinya atau para pihak yang membuat perjanjian telah sepakat atau ada persesuaian kemauan atau saling menyetujui kehendak masing-masing, yang dilahirkan oleh para pihak dengan tiada paksaan, kekeliruan dan penipuan. Persetujuan mana dapat dinyatakan secara tegas maupun secara diam-diam. ${ }^{20}$ Syarat angka 1 dan angka 2 Pasal 1320 KUH Perdata adalah syarat subyektif yang apabila tidak dipenuhi maka suatu perjanjian dapat dibatalkan. Syarat angka 3 dan angka 4 Pasal 1320 KUH Perdata adalah syarat obyektif yang apabila tidak dipenuhi maka suatu perjanjian dapat berakibat batal demi hukum. Dengan demikian, suatu akta dapat dikatakan batal demi hukum apabila akta tersebut tidak memenuhi syarat obyektif yaitu tidak adanya suatu hal tertentu dan tidak ada kausa yang halal dari perjanjian tersebut. Dengan kata lain, perjanjian yang termuat dalam akta tersebut dianggap tidak pernah ada dan tidak dapat mengikat para pihak.

Di sisi lain, Pasal 65 UUJN menyatakan sebagai berikut: "Notaris, Notaris Pengganti, dan Pejabat Sementara Notaris bertanggung jawab atas setiap Akta yang dibuatnya meskipun Protokol Notaris telah diserahkan atau dipindahkan kepada pihak penyimpan Protokol Notaris". Dalam pasal tersebut disebutkan bahwa Notaris bertanggung jawab terhadap setiap akta yang dibuatnya meskipun Protokol Notaris telah diserahkan kepada pihak penyimpan Protokol Notaris. Tanggung jawab merupakan keadaan wajib menanggung segala sesuatunya. Tanggung jawab juga meliputi kesadaran manusia akan tingkah laku atau perbuatannya yang disengaja maupun yang tidak disengaja.

Berkaitan dengan persoalan tanggung jawab Notaris, Habib Adjie ${ }^{21}$ menyatakan:

"Notaris sebagai pejabat publik produk akhirnya yaitu akta otentik, yang terikat dalam ketentuan hukum perdata terutama dalam hukum pembuktian. Akta tidak memenuhi syarat sebagai Keputusan Tata Usaha Negara yang bersifat konkret, individual, dan final dan tidak menimbulkan akibat hukum perdata bagi seseorang atau badan hukum perdata, karena akta merupakan formulasi keinginan atau kehendak (wilsvorming) para pihak yang dituangkan dalam akta Notaris yang dibuat di hadapan atau oleh Notaris dan bukan kehendak Notaris".

Secara konkret, wujud tanggung jawab ialah berupa sanksi baik moral dan/atau hukum. Ditinjau dari sudut sanksi, tanggung jawab Notaris mencakup: tanggung jawab yang bersifat pribadi dan tanggung jawab kelembagaan (organisasi). Sedangkan tanggung jawab hukum dimaksud, bersumber pada UUJN, Hukum Pidana dan Hukum Perdata. ${ }^{22}$ Dari uraian di atas, maka dapat dipahami bahwa tanggung jawab Notaris dapat dilihat dari kewajiban dan wewenang Notaris yang diatur dalam UUJN. Selain itu, Notaris dalam menjalankan jabatannya diharuskan senantiasa bercermin pada etika moral, taat asas serta tunduk dan patuh pada setiap peraturan baik yang mengatur jabatannya maupun perundang-undangan lainnya. Hal ini dimaksudkan agar masyarakat dan semua kalangan benar-benar dapat memaknai profesi Notaris sebagai salah satu profesi yang mulia dan bermartabat. Hal demikian sebagaimana dinyatakan oleh Abdulkadir Muhammad yang dikutip oleh Munir Fuady, ${ }^{23}$ khusus bagi profesi hukum sebagai profesi terhormat, terdapat nilai-nilai profesi yang harus ditaati oleh mereka, yaitu sebagai berikut: a) Kejujuran, b) Otentik; c) Bertanggung jawab; d) Kemandirian moral; e) Keberanian moral.

Terkait dengan tanggung jawab Notaris terhadap akta yang dibuatnya, maka

20. Ridwan Syahrani, 2000, Seluk Beluk dan Asas-asas Hukum Perdata, Bandung, Alumni, hlm.214.

21. Habib Adjie, 2009, Sanksi Perdata dan Administratif terhadap Notaris sebagai Pejabat Publik, Cetakan Pertama, Bandung, PT. Refika Aditama, hlm.163-164.

22.Pieter Latumeten, 2014, "Pertanggungjawaban Hukum Profesi Notaris", Paper pada Seminar Refleksi 106 Tahun Ikatan Notaris Indonesia (INI) dan 27 Tahun Ikatan Pejabat Pembuat Akta Tanah (IPPAT), Bandung, Tanggal 5 September.

23.Munir Fuady, 2005, Profesi Mulia (Etika Profesi Hukum bagi Hakim, Jaksa, Advokat, Notaris, Kurator dan Pengurus), Bandung, PT. Citra Aditya Bakti, hlm.4. 
berkenaan dengan batas waktu tanggung jawab terebut, bilamana suatu akta otentik batal demi hukum, dan dimintakan pertanggungjawaban oleh para pihak yang merasa dirugikan, maka mengunakan ketentuan tentang daluwarsa akta tersebut. Hukum barat mengenal pengertian daluwarsa. Dalam buku keempat BW, antara lain diatur tentang daluwarsa. ${ }^{24}$

Pengertian tentang daluwarsa (verjaring) diatur dalam Pasal 1946 KUH Perdata yaitu sebagai berikut: "Daluwarsa adalah suatu alat untuk memperoleh sesuatu atau untuk dibebaskan dari suatu perikatan dengan lewatnya suatu waktu tertentu dan atas syarat

-syarat yang ditentukan oleh undangundang”. Pasal 1947 KUH Perdata menyatakan bahwa: "Tak diperkenankan seorang melepaskan daluwarsa, sebelum tiba waktunya, namun bolehlah ia melepaskan suatu daluwarsa yang sudah diperolehnya". Selanjutnya Pasal 1967 KUH Perdata menyatakan bahwa, segala tuntutan hukum, baik yang bersifat perbendaan maupun bersifat perseorangan, hapus karena daluwarsa dengan lewatnya waktu tiga puluh tahun, sedangkan siapa yang menunjukkan adanya daluwarsa itu tidak usah mempertunjukkan suatu alas hak, lagi pula tak dapatlah dimajukan terhadapnya sesuatu tangkisan yang didasarkan kepada itikadnya yang buruk. Seseorang tidak dapat memperoleh sesuatu hak karena daluwarsa bila waktunya belum tiba, akan tetapi seseorang dapat melepaskan sesuatu hak yang diperolehnya karena daluwarsa.

Berdasarkan pemaparan mengenai daluwarsa, maka dapat disimpulkan bahwa daluwarsa berdasarkan hukum perdata adalah tiga puluh tahun. Apabila suatu akta otentik yang dibuat dihadapan Notaris telah terbukti berakibat batal demi hukum dan merugikan para pihak maka Notaris dapat dimintakan pertanggung jawabannya meskipun masa jabatan Notaris tersebut telah berakhir. Hal ini dapat dilakukan oleh para pihak sepanjang masa akta otentik batal demi hukum tersebut masih ada yaitu dalam tenggang waktu tiga puluh tahun. Daluwarsa akta terhitung sejak tanggal akta tersebut dibuat.

Dari uraian tentang tanggungjawab Notaris terhadap akad perbankan syariah yang dinyatakan batal demi hokum, maka dapat disimpulkan bahwa jika pihak yang merasa dirugikan dengan status batal tersebut mengajukan gugatan, maka Notaris memang turut bertanggung jawab atas kertugian yang ditimbulkan, sepanjang batas waktu tiga puluh tahun, sejak akad dimaksud dibuat. Hal tersebut baik Notaris yang bersangkutan masih aktif menjalankan fungsi dan jabatan Notaris, maupun telah purna tugas. Megingat panjangnya masa pertanggungjawaban Notaris demikian, maka penting bagi Notaris untuk tidak berbuat kesalahan dalam pembuatan akad.

\section{Simpulan}

Dari keseluruhan uraian tentang Notaris dan Sengketa Perbankan Syariah, maka dapat diambil beberapa simpulan, antara lain :

1. Secara filosofis, historis dan yuridis, terdapat hubungan yang erat antara perbankan syariah, muslim dengan hokum Islam. Hal tersebut dapat dilihat dari fakta empiris sosiologis, serta fakta yuridis berupa dimuatnya prinsipprinsip syariah yang berasal dari hokum Islam secara legal formal dimuat dalam perundang-undangan. Perbankan syariah mempunyai karakteristik khusus dalam keseluruhan aspek operasaionalnya, termasuk dalam sifat, ragam dan konstrusi akad-akadnya.

2. Sebagai pejabat publik, Notaris mempunyai tanggung jawab terhadap setiap akad yang dibuatnya. Tanggungjawab dimaksud berlaku hingga masa 30 tahun sejak dibuatnya suatu akad. Dengan demikian, bila suatu akad dinyatakan batal demi hukum dalam proses penyelesaian sengketa, dan apabila pihak yang merasa dirugikan atas hal tersebut melakukan gugatan, maka Notaris tetap bertanggungjawab, baik masih dalam masa tugas maupun setelah purna. Artinya, Notaris dapat turut menerima

24. Retnowulan Sutantio dan Iskandar Oeripkartawinata, 2005, Hukum Acara Perdata dalam Teori dan Praktek, Bandung, Mandar Maju, hlm.205. 
sanksi hukum dari hakim yang menyelesaikan sengketa, terkecuali jika telah lewat masa daluawarsa.

\section{Daftar Pustaka}

Adjie Habib, 2009, Sanksi Perdata dan Administratif terhadap Notaris sebagai Pejabat Publik, Cetakan Pertama, Bandung, PT. Refika Aditama.

Amirudin dan Zainal Asikin, 2013, Pengantar Metode Penelitian Hukum, Jakarta, Raja Grafindo Perkasa.

Bockrath Joseph T, 2000, Contracts and The Legal Environment for Engineers and Architects, The McGraw-Hill Companies, Inc, United States of America.

Fuady Munir, 2005, Profesi Mulia (Etika Profesi Hukum bagi Hakim, Jaksa, Advokat, Notaris, Kurator dan Pengurus), Bandung, PT. Citra Aditya Bakti.

H.S Salim, 2012, Perkembangan Teori dalam Ilmu Hukum, Cetakan Kedua, Jakarta, PT Rajagrafindo Persada.

HS H. Salim. dan H. Abdullah, 2007, Perancangan Kontrak dan MOU, Jakarta, Sinar Grafika.

Kamenka E. \& Alice Erh-Soon Toy, 1979, Justice, London, Edward Arnold.

Kansil C.S.T, 1986, Pengantar Ilmu Hukum dan Tata Hukum Indonesia, Jakarta, Balai Pustaka.

Kelsen Hans, 1991, eneral Theory of Norms, terjemahan Michael Hartney, New York, Oxford University Press.

Kie Tan Thong, 2011, Studi Notariat dan Serba-Serbi Praktek Notaris, Cetakan Kedua, Jakarta, PT. Ichtiar Baru van Hoeve.

$\mathrm{L}$ a $\mathrm{t} \mathrm{u} \mathrm{me} \mathrm{ten} \mathrm{P}$ i e t e r, 2014 , "Pertanggungjawaban Hukum Profesi Notaris", Paper pada Seminar Refleksi 106 Tahun Ikatan Notaris Indonesia (INI) dan 27 Tahun Ikatan Pejabat Pembuat Akta Tanah (IPPAT), Badung, Tanggal 5 September.

Masriani Yulies Tiena, The Position of Notarial Deed in the Syaria Economic
Dispute, Mimbar Hukum Vol. 28, Nomor 1, Februari 2016, hlm. 162173.

Mertokusumo Sudikno, 1993, Hukum Acara Perdata Indonesia, Edisi Keempat, Yogyakarta, Liberty.

Mertokusumo Sudikno dan Mr. A. Pitlo, 1993, Bab-bab Tentang Penemuan Hukum, Bandung, PT. Citra Aditya Bakti.

Prajitno A.A. Andi, 2010, Apa dan Siapa Notaris di Indonesia?, Cetakan Pertama, Surabaya, Putra Media Nusantara.

Rahardjo Satjipto, 2006, Hukum Dalam Jagat Ketertiban, Cetakan I, Jakarta, UKI Press.

Samudera Teguh, 2004, Hukum Pembuktian dalam Acara Perdata, Edisi Pertama, Bandung, Alumni.

Sutantio Retnowulan dan Iskandar Oeripkartawinata, 2005, Hukum Acara Perdata dalam Teori dan Praktek, Bandung, Mandar Maju.

Syahrani Ridwan, 2000, Seluk Beluk dan Asas-asas Hukum Perdata, Bandung, Alumni.

Tobing G.H.S Lumban, 1999, Peraturan Jabatan Notaris, Jakarta, Erlangga.

Tresna R, 1993, Komentar HIR, Jakarta, Pradnya Paramita.

Yusup Deni K, Peran Notaris Dalam Praktek Perjanjian Bisnis Di Perbankan Syariah (Tinjauan Dari Perspektif Hukum Ekonomi Syariah), Jurnal Al 'Adalah, Vol. XXI, No. 4, Desember 2015. 